\title{
A COMPARISON OF CHOLESTERYL OLEATE AND 19-IODOCHOLESTERYL OLEATE AS SUBSTRATES FOR ADRENAL CHOLESTEROL ESTERASE
}

\author{
G. D. Nordblom, L. W. Schappa, E. E. Floyd, R. B. Langdon and R. E. Counsell* \\ Department of Pharmacology, The University of Michigan Medical School, Ann Arbor. \\ Michigan 48109, U.S.A.
}

(Received 27 June 1979)

\section{SUMMARY}

\begin{abstract}
Radiolabeled 19-iodocholesterol is widely used to obtain images of human adrenals. We have shown in rats and mice that $85-95 \%$ of the radiolabel is present in the esterified form. Using rat adrenal cytosolic cholesterol esterase, the kinetic parameters $K_{M}$ and $V$ were determined for commercially available cholesteryl $\left[1-{ }^{14} \mathrm{C}\right]$-oleate (I) and $\left[{ }^{125} \mathrm{I}\right]$-19-iodocholesteryl oleate (II). The $\mathrm{K}_{M}$ and $V$ were found to be $16.2 \mu \mathrm{M}$ and $602 \mathrm{pmol} / \mathrm{min} / \mathrm{mg}$ prot. respectively for I compared to $76.2 \mu \mathrm{M}$ and $37.6 \mathrm{pmol} / \mathrm{min} / \mathrm{mg}$ prot for II. Since $V / K_{M}$ is $37.3 \mathrm{ml} / \mathrm{min} / \mathrm{mg}$ prot. for the normal ester and $0.49 \mathrm{ml} / \mathrm{min} / \mathrm{mg}$ prot. for the iodinated analog, it appears that the normal substrate is 76 times more specific than II. In addition, direct competition experiments were run in which $67 \mu \mathrm{M} \mathrm{I}$ was used as substrate. The addition of 65 and $325 \mu \mathrm{M} 19$-iodocholesteryl oleate caused 20 and $49 \%$ inhibition, respectively. On the basis of these studies, it is not surprising that 19-iodocholesterol would accumulate in the adrenals in an esterified form and thus provide an effective agent for adrenal visualization.
\end{abstract}

\section{INTRODUCTION}

In 1969 we reported the synthesis of $\left[{ }^{125} \mathrm{I}\right]-19$ iodocholest-5-en-3 $\beta$-ol $\left(\left[{ }^{125} \mathrm{I}\right]\right.$-19-iodocholesterol) and its ability to selectively concentrate in male dog adrenals [1]. At $48 \mathrm{~h}$ following intravenous administration, the concentration of radioactivity in the adrenals was 30 times that in liver and blood. Shortly after these studies, the first images of human adrenals were obtained with $\left[{ }^{131} I\right]-19$-iodocholesterol [2]. This agent has now been widely used to diagnose a variety of adrenal disorders in humans such as functional [3] and nonfunctional $[4,5]$ adrenocortical carcinomas, primary aldosteronism [6], and Cushing's syndrome [7]. This paper explores one facet of cholesterol metabolism that may account for 19-radioiodinated cholesterol's ability to act as an adrenal imaging agent.

It is well known that, of all the organs, the adrenal gland has the highest concentration of cholesterol. In the rat, for example, $5 \%$ of the net weight of the adrenal cortex is comprised of cholesterol, most of which is esterified [8]. There are potentially two major sources of cholesterol available to the cell to meet its metabolic needs: namely, that delivered directly by lipoproteins and that biosynthesized de novo from acetyl-CoA [9]. The cell also maintains a large store of cholesterol as esters which can be hydrolyzed to free sterol.

In our early studies on the disposition of $\left[{ }^{125} I\right]-19$ iodocholesterol in dogs [1]. we found most of the

* To whom correspondence and reprint requests should be addressed. lipid extractable radioactivity from the adrenals to be associated with the cholesterol ester fraction. Similarly, later studies in female rats showed that greater than $90 \%$ of the radioactivity in both the adrenals and ovaries was present as radioiodinated cholesterol esters [10]. Clearly, in both dogs and rats. 19-iodocholesterol appears to mimic cholesterol in its ability to be taken up and esterified in those organs involved in steroidogenesis. Since cholesterol esters must first be hydrolyzed to free cholesterol before they can be utilized for steroid hormone biosynthesis [11], it was of interest to ascertain the suitability of 19-iodocholesterol esters to serve as substrates for adrenal cholesterol esterase [EC 3.1.1.13]. We report here on the comparison of kinetic parameters $\left(K_{M}\right.$ and $\left.V\right)$ for $\left[{ }^{125} \mathrm{I}\right]$-19-iodocholesteryl oleate and cholesteryl $\left[1-{ }^{14} \mathrm{C}\right]$-oleate using adrenal, cytosolic enzyme preparations.

\section{MATERIALS AND METHODS}

\section{Materials}

$\left[9,10{ }^{3} \mathrm{H}(\mathrm{N})\right]$-Oleic acid $(5.66 \mathrm{Ci} / \mathrm{mmol})$ and substrate, cholesteryl $\left[1-{ }^{14} \mathrm{C}\right]$-oleate $(51 \mathrm{mCi} / \mathrm{mmol})$ were obtained from New England Nuclear, Boston. Mass. Aliquots from the original stock solution were diluted with either cholesteryl oleate or oleic acid. reagent grade, obtained from Sigma Chemical Company, until final activities were approximately $2.2 \mu \mathrm{Ci} / \mu \mathrm{mol}$ and $1 \mu \mathrm{Ci} / \mu \mathrm{mol}$ for cholesteryl oleate and oleic acid respectively. Radiochemical purity of each solution was checked by thin layer chromatography, t.l.c., using the solvent system hexane-diethyl ether-glacial acetic 
acid $(80: 20: 1.75, \mathrm{v} / \mathrm{v})$. 19-Iodocholesterol was a gift from Searle Laboratories, Skokie, Ill. Oleoyl chloride was from $\mathrm{Nu}$-Chek-Prep Co. ATP $(99 \%$ pure) and cAMP (97\% pure) were obtained from Sigma Chemical Company. $\beta$-Mercaptoethanol was obtained from Matheson, Coleman and Bell. All other chemicals used in assays were of reagent grade.

\section{Preparation of 19-iodocholest-5-en-3 $\beta$-ol oleate}

A mixture of 19-iodocholesterol $(100 \mathrm{mg}$ $0.194 \mathrm{mmol}$ ), oleoyl chloride $(100 \mathrm{mg}, 0.332 \mathrm{mmol})$ and triethylamine $(20.2 \mathrm{mg}, 0.200 \mathrm{mmol})$ in $25 \mathrm{ml}$ of dry benzene was stirred at room temperature under $\mathrm{N}_{2}$ for $24 \mathrm{~h}$. The solvent was removed in vacuo yielding a yellow residue which was stirred with $2 \mathrm{ml}$ of $\mathrm{H}_{2} \mathrm{O}$ for $2 \mathrm{~h}$. The aqueous mixture was then extracted three times with $100 \mathrm{ml}$ of ether. The combined ether layers were washed with $\mathrm{H}_{2} \mathrm{O}$ and dried with $\mathrm{Na}_{2} \mathrm{SO}_{4}$. Evaporation of the organic solvent yielded an oil that was purified on a $1.3 \times 40 \mathrm{~cm}$ silica gel column using benzene as an eluant. 19-Iodocholest-5en-3 $\beta$-ol oleate was isolated as a clear oil $(130 \mathrm{mg}$. $86 \%$ ): I.R., $V_{\max } 1733 \mathrm{~cm}^{-1}$; NMR, p.p.m. $\left(\mathrm{CDCl}_{3}\right)$; $0.84\left(\mathrm{~s}, 3 \mathrm{H}, 18-\underline{\mathrm{CH}}_{3}\right), 3.30$ and 3.63 (dd, $2 \mathrm{H}, 19-\underline{\mathrm{CH}}_{2} \mathrm{I}$ ), $4.64(\mathrm{~m}, 1 \mathrm{H}, 3 \alpha-\underline{\mathrm{H}}), 5.38(\mathrm{t}, 2 \mathrm{H}$, oleic vinyl $\underline{\mathrm{H}}), 5.71$ (m, 1H, 6-H). Anal. Calcd. $\mathrm{C}_{45} \mathrm{H}_{77} \mathrm{O}_{2} \mathrm{I}$ : C, 69.56; H, 9.99. Found: C, 69.62; H 9.78.

\section{Preparation of $\left[{ }^{125} I\right]-19$-iodocholest-5-en-3 $\beta$-ol oleate}

Aqueous $\mathrm{Na}\left[{ }^{125} \mathrm{I}\right](3.4 \mathrm{mCi}, 250 \mu \mathrm{l})$ was placed in a $15 \mathrm{ml}$ round bottom flask and the $\mathrm{H}_{2} \mathrm{O}$ evaporated with a stream of $\mathrm{N}_{2}$. 19-Iodocholest-5-en-3 $\beta$-ol oleate $(8.4 \mathrm{mg}, 10.8 \mathrm{mmol})$ in $2 \mathrm{ml}$ of dry acetone was added to the $\mathrm{Na}\left[{ }^{125} \mathrm{I}\right]$ and the mixture was refluxed under $\mathrm{N}_{2}$ for $4 \mathrm{~h}$. The acetone was evaporated with $\mathrm{N}_{2}$ and $\mathrm{H}_{2} \mathrm{O}(1 \mathrm{ml})$ added to the flask. The aqueous phase was extracted with benzene $(4 \times 1 \mathrm{ml})$. The combined organic layer was placed on a $1.4 \times 4.5 \mathrm{~cm}$ silica gel column and eluted with benzene. A clear oil $(7.0 \mathrm{mg}$, $2.2 \mathrm{mCi}$ ) was isolated. Thin-layer chromatography of this product on Eastman Chromatogram silica gel plates with benzene showed a single spot $\left(R_{F}=0.56\right)$ which co-migrated with authentic 19-iodocholest-5en-3 $\beta$-ol oleate. Aliquots of $\left[{ }^{125} I\right]-19$-iodocholesteryl oleate were diluted with stable material in acetone to a final concentration of $300 \mu \mathrm{Ci} / \mu \mathrm{mol}$ and stored at $4^{\circ} \mathrm{C}$ until used.

Under certain conditions 19-iodocholesterol has been shown to rearrange to $6 \beta$-iodomethyl-19norcholest-5(10)-en-3 $\beta$-ol $[12,13]$. However, the nmr spectrum for 19-iodocholesterol used in these studies agreed with published data $[12,14]$. The subsequent isotope exchange reaction was performed in refluxing acetone, conditions which are known to not cause rearrangement [15]. In addition, rearrangement would not be expected to occur in vitro.

\section{Solutions}

The following is a description of the solutions used for either the cholesteryl esterase assays or for the enzyme preparation: Buffer I-0.25 M sucrose, $10 \mathrm{mM}$ potassium phosphate (pH 7.4); Buffer II-0.25 M sucrose, $10 \mathrm{mM}$ potassium phosphate $(\mathrm{pH} \mathrm{7.4)}$ and $5 \mathrm{mM} \beta$-mercaptoethanol; Cofactor solution-10 mM $\mathrm{MgCl} .6 \mathrm{H}_{2} \mathrm{O}, 100 \mathrm{mM}$ Tris- $\mathrm{HCl}, 5 \mathrm{mM} \beta$-mercaptoethanol, $50 \mathrm{mM} \mathrm{KCl}, 10 \mathrm{mM} \quad \mathrm{Na}_{2}$ ATP. $4.5 \quad \mathrm{H}_{2} \mathrm{O}$, $0.2 \mu \mathrm{M}$ dibutyryl cAMP, $\mathrm{pH}$ of this mixture was adjusted to 7.4 with $5 \% \mathrm{NaOH}$ before addition to assay tubes.

\section{Enzyme preparation}

The procedure for enzyme preparation was a modification of the method by Trzeciak and Boyd[16]. Adult female rats $(200 \mathrm{~g})$, obtained from Spartan Research Animals Inc., Haslett, Mich., were sacrificed by ether overdose and the adrenals quickly removed and pooled in $5.0 \mathrm{ml}$ Buffer I. Adrenals were homogenized in $10 \mathrm{ml}$ Buffer $I$ and the homogenate transferred to plastic Sorvall tubes and centrifuged as previously described at $4^{\circ} \mathrm{C}$. The resulting supernatant layer was then dialyzed at $4^{\circ} \mathrm{C}$ against Buffer II, $2 \times 500 \mathrm{ml}$ for $24 \mathrm{~h}$ to remove endogenous lipid. The dialyzed crude preparation was stored in $0.5 \mathrm{ml}$ aliquots at $-20^{\circ} \mathrm{C}$ until needed. Protein concentration was determined by the method of Lowry and co-workers, as modified by Miller[17].

\section{Cholesteryl $\left[1-{ }^{14} \mathrm{C}\right]$ oleate hydrolysis assay}

The following procedure was based on studies by Pittman and Steinberg[18] with some modifications. Cholesteryl esterase activity was measured in pmol/ $\mathrm{min} / \mathrm{mg}$ protein by the release of $\left[1-{ }^{14} \mathrm{C}\right]$-oleate from the substrate cholesteryl $\left[1-{ }^{14} \mathrm{C}\right]$-oleate, using tritiated oleic acid as a means of ascertaining recovery of standard. Total volume of the reaction mixture was kept constant at $0.34 \mathrm{ml}$. Contents of the reaction mixture included: Cofactor solution $150 \mu \mathrm{l}$; Buffer II $100 \mu \mathrm{l}$; substrate cholesteryl $\left[1-{ }^{14} \mathrm{C}\right]$-oleate $\leq 20 \mu \mathrm{l}$; and acetone ( $20 \mu$ l-volume of substrate). The amount of acetone was kept constant at $20 \mu \mathrm{l}$ in each tube since at this assay volume, acetone in excess of $25 \mu$ l begins to have inhibitory effects on the enzyme. The assay was initiated by the addition of either $70 \mu \mathrm{l}$ of Buffer II to control tubes or $0.091 \mathrm{mg}$ enzyme to experimental tubes. The reaction was terminated by the addition of $6 \mathrm{ml} \mathrm{CHCl}-\mathrm{CH}_{3} \mathrm{OH}(2: 1, \mathrm{v} / \mathrm{v})$ with vigorous vortexing. $\left[9,10^{-3} \mathrm{H}(\mathrm{N})\right]$-Oleic acid $[15 \mu \mathrm{g} / 20 \mu \mathrm{l}$, 100,000 d.p.m.] was added to serve as a recovery standard. Magnesium chloride $(1.2 \mathrm{ml}, 0.035 \%$ soln $)$ was then added to partition the mixture into an upper aqueous and lower organic phase. The bottom organic layer was removed and evaporated to dryness under a stream of $\mathrm{N}_{2}$ in a water bath at $37^{\circ} \mathrm{C}$. The residues were redissolved in ether, $2 \times 15$ drops, which were spotted on Eastman Chromatogram silica gel plates. Plates were developed to a solvent front distance of $16 \mathrm{~cm}$ in hexane-diethyl ether-glacial acetic acid $(80: 20: 1.75, \mathrm{v} / \mathrm{v})$. A radioscan of the plates showed the substrate peak to be at $R_{F}=0.64$ and the product peak to be at $R_{F}=0.11$. That portion of the 
plate corresponding to the product, oleic acid, was removed and placed in liquid scintillation counting vials. Ethanol $(1.5 \mathrm{ml}, 95 \%)$ was added and the vials slowly shaken for $5 \mathrm{~min}$ to elute activity from the plate. Toluene with $6 \mathrm{~g} / 1$ ppo and $0.075 \mathrm{~g} / 1$ popop cocktail $(10 \mathrm{ml})$ was added and vials were counted in a Packard liquid scintillation spectrophotometer at dual isotope settings which have been optimized to provide maximum isotope efficiency under the quench conditions encountered with this procedure. ${ }^{14} \mathrm{C}$ and ${ }^{3} \mathrm{H}$ counts were converted to "d.p.m." according to the equation for double isotope counting by Hendee[19]. All graphical plots were derived from the equation for a weighted fit of a linear regression described by Wilkinson[20].

\section{['1]-19-Iodocholesteryl oleate hydrolysis assay}

The procedure for $K_{m}$ determination of this substrate followed closely with that described above with a few exceptions. Cholesteryl esterase activity was measured by the release of $\left[{ }^{125} \mathrm{I}\right]$-19-iodocholesterol from the substrate $\left[{ }^{125} I\right]$-19-iodocholesteryl oleate. TLC plates were spotted as above but developed in a solvent system of benzene-ethyl acetate $(9: 1, \mathrm{v} / \mathrm{v})$. Under these conditions, the substrate peak appeared at $R_{F}=0.73$ and the product peak at $R_{F}=0.23$. Portions of the plate representing both substrate and product peaks were cut and assayed for radioactivity in a Searle Model 1185 gamma counter. Counting efficiency for $\left[{ }^{125} \mathrm{I}\right]$ was $87 \%$.

\section{Competition assay}

Conditions for this assay followed that for the cholesteryl oleate hydrolysis assay except only one concentration of cholesteryl $\left[1-{ }^{14} \mathrm{C}\right]$-oleate was used. Cholesteryl $\left[1-{ }^{14} \mathrm{C}\right]$-oleate was added in a volume of $10 \mu 1$ to a final concentration of $67 \mu \mathrm{M}$. This concentration was chosen well within the plateau range of enzyme saturation according to the classical Michaelis--Menton concept, so that any variance in substrate concentration, from experimental error, would not significantly alter the velocity of the product formed. The inhibitor, 19-iodocholesteryl oleate was added in a volume of $10 \mu \mathrm{l}$ to final concentrations of 65 and $325 \mu \mathrm{M}$.

\section{RESULTS}

The velocity of hydrolysis was determined for iodinated and non-iodinated cholesteryl esters at varying concentrations of substrate. The reciprocal of the velocity was then plotted with respect to the reciprocal of the concentrations of the substrate to obtain classical Lineweaver-Burk plots. Two parameters, $V$ and $K_{M}$ were thus determined.

An enzyme exhibits two types of specificity toward substrates, binding specificity as reflected in the $K_{M}$ values, and the kinetic specificity as reflected in the $V$ values [21]. Since it is not uncommon for substrates to have similar $K_{M}$ values but vastly different $V$ values [22] or the reverse, the most meaningful kinetic constant for comparison of substrate specificity is the ratio $V / K_{M}[23]$.

The $K_{M}$ and $V$ cholesteryl oleate were determined in six experiments and calculated to be $16.2 \mu \mathrm{M} \pm 3.4$ and $602 \mathrm{pmol} / \mathrm{min} / \mathrm{mg}$ protein \pm 233 respectively. Large variations in cholesterol esterase activity have been reported previously by Pittman and Steinberg[18]. They showed that $K_{M}$ values could vary from 4.2 to $63 \mu \mathrm{M}$ and that the variation of $V$ could be by as much as $50 \%$ depending on the amount of lipid associated with the enzyme and the amount of ATP, cyclic AMP and protein kinase (EC 2.7.1.37) present in the preparations. Cholesterol ester hydrolysis is stimulated by corticotropin via an adenylate cyclase, cyclic AMP. protein kinase pathway $[23,24]$ and consequently these variables along with the method of sacrifice of the animals (stress from ether anaesthesia raises corticotropin levels [25]) can greatly affect enzyme activity.

We found that to optimize conditions and to get reproducible results we had to dialyze our preparations to remove lipid and activators from endogenous protein kinase and then add back known amounts of ATP, dibutyryl cyclic AMP and $\mathrm{MgCl}_{2}$. All L" these factors are known to stimulate enzyme activity [18]. After optimizing the conditions of the assay, a kinetic study was performed on $\left[{ }^{125} \mathrm{I}\right]-19$. iodocholesteryl oleate. The $K_{M}$ was calculated to be $76.2 \mu \mathrm{M}$ and $V 37.6 \mathrm{pmol} / \mathrm{min} / \mathrm{mg}$ protein.

To ascertain whether the iodinated ester was hydrolyzed at the same active site as the normal substrate, a direct competition experiment was carried out in which $67 \mu \mathrm{M}$ cholesteryl $\left[1-{ }^{14} \mathrm{C}\right]$-oleate was hydrolyzed in the presence of $65 \mu \mathrm{M}$ and $325 \mu \mathrm{M}$ of 19-iodocholesteryl oleate. These concentrations of 19-iodocholesteryl oleate caused a 20 and $49 \%$ inhibition. respectively of $\left[1-{ }^{14} \mathrm{C}\right]$-oleic acid formation.

\section{DISCUSSION}

On the basis of the kinetic data obtained for the two substrates, two qualitative statements can be made concerning the relative nature of the two substrates. As shown in Table 1 , the $K_{M}$ of 19-iodocholesteryl oleate is only about four times greater than the

Table 1. Kinetic parameters

\begin{tabular}{lccc}
\hline \multicolumn{1}{c}{ Substrate } & $V(\mathrm{pmol} / \mathrm{min} / \mathrm{mg})$ & $K_{M}(\mu \mathrm{M})$ & $V / K_{M}(\mathrm{ml} / \mathrm{min} / \mathrm{mg})$ \\
\hline Cholesteryl oleate & 602.0 & 16.2 & 37.30 \\
19-Iodocholesteryl oleate & 37.6 & 76.2 & 0.49 \\
\hline
\end{tabular}


normal substrate, the binding specificity of this analog is roughly the same as the normal substrate. However, the $V$ values indicate that the enzyme has a much greater kinetic specificity for the normal substrate. Moreover, when the parameters $V / K_{M}$ are compared $(37.3 \mathrm{ml} / \mathrm{min} / \mathrm{mg}$ protein for cholesteryl oleate and $0.49 \mathrm{ml} / \mathrm{min} / \mathrm{mg}$ protein for 19 -iodocholesteryl oleate). it appears that the normal substrate is about 76 times more specific than the iodinated analog. Despite the lower kinetic specificity of 19-iodocholesteryl oleate, the competition experiment suggests that this iodinated compound competes for the same activity site as the normal ester.

These findings offer one explanation for the accumulation of 19-iodocholesterol in the adrenals and ovaries of animals and man. Once transported and stored in the esterified form in the endocrine organs, the 19-iodocholesterol esters remain unchanged because the enzyme cholesterol esterase has a lower binding specificity coupled with a significantly lower kinetic specificity for the iodinated ester. This concept is supported by the recent findings of Rizza et al.[5]. In their studies, rats were treated with either $\left[{ }^{131} \mathrm{I}\right]$-19-iodocholesterol or $\left[7-{ }^{3} \mathrm{H}\right]$-cholesterol. Corticotropin, which increases steroid biosynthesis by activating cholesterol esterase $[23,24]$, was then administered to the rats. The corticotropin decreased the $\left[7-{ }^{3} \mathrm{H}\right]$-cholesterol level in the lipid fraction but not that for $\left[{ }^{131} I\right]-19$-iodocholesterol. Although the authors did not establish the nature of the cholesterol present in the lipid fraction, it was undoubtedly esterified as we have shown previously $[1,10]$. These studies in conjunction with our own demonstrate that 19-iodocholesteryl esters are much poorer substrates for cholesterol esterase than normal cholesteryl esters. In light of these findings, the ability of 19-radioiodinated cholesterol to selectively accumulate in the adrenals and ovaries of animals is not surprising.

Acknowledgements--This study was supported in part by USPHS Grant CA-D8349 and by a University of Michigan Biomedical Research Support Grant. The authors wish to thank Searle Laboratories for providing 19-iodocholesterol for the synthetic work.

\section{REFERENCES}

1. Counsell R. E., Ranade V. V.. Blair R. J.. Beierwaltes W. H. and Weinhold P. A.: Tumor localizing agents. IX. Radioiodinated cholesterol. Steroids 16 (1969) 317-328.

2. Blair R. J., Beierwaltes W. H., Lieberman L. M., Boyd C. M., Counsell R. E., Weinhold P. A. and Varma V. M.: Radiolabelled cholesterol as an adrenal scanning agent. J. Nucl. Med. 12 (1971) 176-182.

3. Lieberman L. M., Beierwaltes W. H., Conn J. W., Ansari A. N. and Nishiyama H.: Diagnosis of adrenal disease by visualization of human adrenal glands with ${ }^{131}$ I-19-iodocholesterol. N. Engl. J. Med. 285 (1971) 1387-1393.

4. Beierwaltes W. H., Sturman M. F., Ryo U. and Ice R.: Imaging functional nodules of the adrenal glands with ${ }_{131}$ I-19-iodocholesterol. J. Nucl. Med. 15 (1974) 246-251.

5. Rizza R. A., Whaner W. W., Spelsberg T. C., Northcutt R. C. and Moses H. L.: Visualization of nonfunction- ing adrenal adenomas with iodocholesterol: Possible relationships to subcellular distribution of tracer. $J$. Nucl. Med. 19 (1978) 458-463.

6. Conn J. W., Morita R., Cohn E. L., Beierwaltes W. H., McDonald W. J. and Herwig K. R.: Primary aldosteronism: photoscanning of tumors after administration of ${ }^{131}$ I-19-iodocholesterol. Arch. Intern. Med. 129 (1972) 417-425.

7. Morita R., Lieberman L. M., Beierwaltes W. H., Conn $J$. W. Ansari A. N. and Nishiyama $H$.: Percent uptake of ${ }^{13 i} \mathrm{I}$ radioactivity in the adrenal from radioiodinated cholesterol. J. Clin. endocr. Metab. 34 (1972) 36-43.

8. Moses H. L., Davis W. W., Rosenthal A. J. and Garren L, D.: Adrenal cholesterol: localization by electronmicroscope autoradiography. Science 163 (1969) 1203-1205.

9. Anderson J. M. and Dietschy J. M.: Relative importance of high and low density lipoproteins in the regulation of cholesterol synthesis in the adrenal gland. ovary and testis of the rat. J. hiol. Chem. 253 (1978) 9024-9032.

10. Korn N.. Nordblom G., Floyd E. and Counsell R. E.: Potential organ or tumor imaging agents: XX. Ovarian imaging with 19-radioiodinated cholesterol. J. Pharm. $\mathrm{Sci}$. in press.

11. Schulster D.. Burstein S. and Cooke B. A.: Molecular Endocrinology of the Steroid Hormones, Wiley, New York (1976) pp. 187-190.

12. Maeda M., Kojima M., Ogawa H., Nitta K. and Ito T.: Homoallylic rearrangement of 19-iodocholest-5en$3 \beta$-ol: New adrenal scanning agent. Steroids 26 (1975) 241-250.

13. Scott K. N., Couch M. W., Mooreci T. H. and Williams C. M.: Synthesis and Purification of Radioactive $6 \beta$-Iodomethyl-19-Norcholest-5(10)-en-3 $\beta$-ol. Steroids 28 (1976) 295-303.

14. Hadd H. E.: A new and improved synthesis of 19-iodocholesterol 3-acetate. Steroids 31 (1978) 453-461.

15. Couch M. W. and Williams C. M.: Comparison of 19-iodocholesterol and 6-iodomethyl-norcholesterol as adrenal-scanning agents. J. Nucl. Med. 18 (1977) 724-727.

16. Trzeciak W. H. and Boyd G. S.: The effect of stress induced by ether anaesthesia on cholesterol content and cholesteryl-esterase activity in rat-adrenal cortex. Eur. J. Biochem. 37 (1973) 327-333.

17. Miller G. L.: Protein determination for large numbers of samples. Analyt. Chem. 31 (1959) 964-973.

18. Pittman R. C. and Steinberg D.: Activatable cholesterol esterase and triacylgylcerol lipase activities of rat adrenal and their relationship. Biochem. biophys. Acta 487 (1977) $431-444$.

19. Hendee W. R.: Radioactive Isotopes in Biological Research. Wiley, New York (1973) pp. 212-215.

20. Wilkinson G. N.: Statistical estimations in enzyme kinetics. Biochem. J. 80 (1961) 324-332.

21. Bender M. L. and Brubacher L. J.: Catalysis and Enzyme Action. McGraw-Hill, New York (1973) pp. 30-31.

22. ibid 183-184.

23. Bender M. L.: Mechanisms of Homogeneous Catalysis from Protons to Proteins. Wiley-Interscience, New York (1971) pp. 622-639.

24. Garren L. D., Gill G. N., Masui H. and Walton G. M.: Recent Progress in Hormone Research (ed. by E. B. Astwood). Academic Press, New York (1971) pp. 433-478.

25. Halkerston I. D. K.: Advances in Cyclic Nucleotide Research (ed. by P. Greengard and G. A. Robinson). Raven Press, New York (1975) pp. 99-136.

26. Matasyuma-H., Rukmann-Wenhold A. and Nelson D. H.: Radio-immunoassay of Plasma ACTH in Intact Rats. Endocrinology 88 (1971) 692-695. 